\title{
Аудиометрични изследвания при пациенти с $\beta$-таласемичен синдром
}

Audiological examination by patients with $\beta$-thalassemic syndrome

\author{
П. Ненчева ${ }^{1}$, П. Руев ${ }^{1}$, П. Димов ${ }^{1}$, М. Рангелова², Д. Стоянова ${ }^{3}$ \\ ${ }^{1}$ Клиника УНГ-болести, МБАЛ - Ст. Загора (Университетска) \\ ²ектор по таласемии, НЦХТ - София \\ ${ }^{3}$ Кабинет по таласемия, СБАЛДБ - София \\ P. Nencheva, P. Rouev, P. Dimov, M. Rangelova, D. Stoyanova
}

Abstract

Introduction: As a reason for hearing disorders by patients with thalassemic syndromes are underlined the ototoxicity of deferoxamine in the therapy of the thalassemia.

Objective: The aim of the study is to establish the presence of hearing disorders by patients with thalassemic syndromes under regular haemotransfusions and chelating therapy.

Study design: Multicentre prospective research - ENT Clinic, Paediatric Clinic, Therapeutic Clinic, Medicine Faculty, Stara Zagora; 6-th Therapeutic Department, District Hospital "Prof. S. Kirkovich“, Stara Zagora; Sector of Thalassemia, Paediatric Hospital, Sofia; Sector of Thalassemia, National Centre of Transfusiology, Sofia.

Material and Methods: 63 patients with $\beta$-thalassemia under regular haemotransfusions and chelating therapy were examinated. For the assessment of the hearing function were used otoacoustic emissions, audiometry and brainstem evoked potentials.

Results: By 15 patients with thalassemic syndromes (23.81\%) were registreted abnormal audiogram's - neurosensorial hearing disorder. By 4 of them the hearing disorder was combining. Disscusion: Our results by assessment of the hearing function are not so different of the results in the studies of many authors.

Key words: $\beta$-thalassemia, hearing disorders, chelating therapy

\section{Резюме}

Увод: Като причина за намаление на слуха при таласемични пациенти се изтъква ототоксичното действие на хелатиращия агент deferoxamine в хода на лечението.

Цел: Целта на настояшото проучване с да се установи наличието на слухови уврсждания при пациенти с $\beta$-талассмичен синдром, подложени на редовна хемотрансфузионна и хелатираща терапия.

\section{Въведение}

Повечето проучвания на слуховите увреждания при пациенти с $\beta$-таласемия са от региони, в които честотата на таласемичните синдроми е по-висока от тази в България. По данни на лабораторията по молекулярна патология към Медицински университет - София пациентите с установен генетично $\beta$-таласемичен синдром в България са 214 [10]. Таласемичните синдроми са разпространени главно в районите на Средиземноморието, Северна Африка и Азия. Сравнително по-високата честота на таласемиите се обяснява с устойчивостта на хетерозиготите за $\beta$-таласемия към маларията [7].

При повечето проучвания проследяването на слуховите увреждания при пациенти с $\beta$-таласемичен синдром е за различен период от време, като средно то варира между 3 и 5 години. Основно слуховите увреждания са невросензорни, и то във високочестотния диапазон. Честотата на слуховите увреждания варира в широки граници - от $1.95 \%$ до $66.7 \%$, като средната честота на невросензорна слухова загуба при пациенти с $\beta$-таласемия е между 20-33\% [2, 5].

Като основна причина за хипоакузис при изследваните пациенти с $\beta$-таласемия повечето автори изтъкват ототоксичното действие на хелатиращия агент deferoxamine, като във високи дози deferoxamine проявява ототоксичност, която при част от болните е 
Дизайн на статията: Мултищснтрово проспективно проучване от: Клиника ОРЛ, Клиника по педиатрия, Клиника по вътрешни болести, Медицински факултет, Стара Загора; VI Вътрешно отделение, МБАЛ "Проф. Ст. Киркович" - Стара Загора; Кабинет по таласемия, СБАЛДБ, София; Сектор по таласемии, НЦХТ, София.

Материал и методи: Изследвани са 63 пациенти с $\beta$-таласемичен синдром, подложени на редовна хемотрансфузионна и хелатираща терапия. За оценка на слуховата функция са използвани тимпанометрия, отоакустични емисии, прагова аудиометрия и слухови стволови евокирани потенциали.

Резултати: При 15 от изследваните от нас пациенти (23.81\%) регистрирахме абнормни аудиограми - лекостепенна невросензорна слухова загуба. При 4 от тях се касаеше за комбинирано намален слух.

Объъждане: Получените от нас резултати при изследването на слуховата функшия на пациенти с таласемичен синдром не се отличават съществено от данните в достъпната литература.

Ключови думи: $\beta$-таласемичен синдром, намаление на слуха, хелатираща терапия, оценка на слуха. обратима след оптимизиране на терапевтичната доза и схемата на лечение [2].

\section{Цел}

В настоящото проучване си поставихме за цел да изследваме проявата на слухови нарушения при пациенти с $\beta$-таласемия майор, подложени на редовна хемотрансфузионна и хелатираща терапия.

\section{Материал и методи}

Проспективното проучване се провежда в четири центъра на територията на България - Клиника ОРЛ, Клиника по педиатрия, Клиника по вътрешни болести, Медицински факултет, Стара Загора; VI Вътрешно отделение, МБАЛ "Проф. Ст. Киркович“ - Стара Загора; Кабинет по таласемия, СБАЛДБ, София; Сектор по таласемии, НЦХТ, София.

В проучването участват 63 пациенти с $\beta$-таласемия, подложени на редовна хемотрансфузионна терапия веднъж на три седмици в зависимост от претрансфузионния хемоглобин и хелатираща терапия за пет дни в седмицата в доза съобразно телесното тегло. Популационните данни за групата пациенти са представени на Фиг. 1.

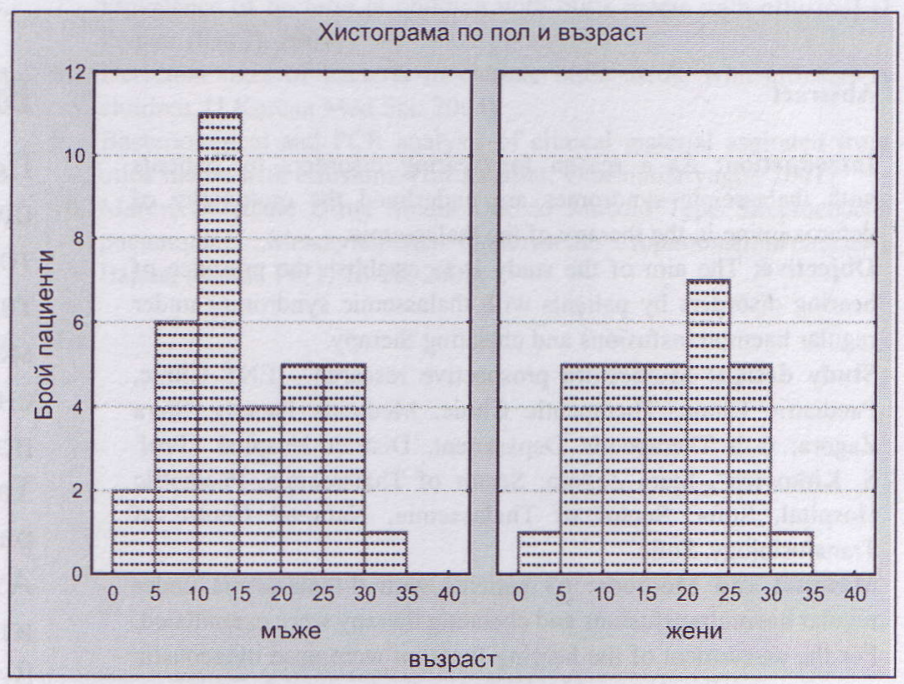

Фиг. 1. Разпределение на пациентите по пол и възраст

Основните клинико-диагностични методи за изследване на слуховата функция при пациентите с таласемичен синдром са тонална прагова аудиометрия, отоакустични емисии и слухови стволови евокирани потенциали. За определяне характера и степента на намаления слух при изследваните от нас пациенти бе използвана тонална прагова аудиометрия, извършена с аудиометър - модел Grahnert Pracitronic GmbH, 2000. Използвана e Caldwell Excel за слухови стволови евокирани потенциали и DPOAE тест система - MAICO ERO SCAN Screener за регистриране на дисторзионни продукти на отоакустични емисии. 


\section{Резултати}

Субективно намален слух регистрирахме само при един от изследваните 63 пациенти с $\beta$-таласемия $(1.58 \%, \mathrm{n}=63)$. При него отчетохме намален минимален праг на слуха за въздушна проводимост на дясно ухо $50 \mathrm{~dB}$ за честотите $125 \div 1000$ $\mathrm{Hz}, 35 \mathrm{~dB}$ за $2000 \mathrm{~Hz}, 40 \mathrm{~dB}$ за $4000 \div 6000 \mathrm{~Hz}$ и $45 \mathrm{~dB}$ за $8000 \mathrm{~Hz}$. При този пациент въздушнокостният интервал беше със стойност над $30 \mathrm{~dB}$ при честоти $125 \div 1000$ и $8000 \mathrm{~Hz}$ за дясното ухо и близък до $30 \mathrm{~dB}$ за честоти 2000 и $4000 \mathrm{~Hz}$. Аудиометричният Weber латерализираше надясно. В случая се касаеше за хроничен серозен отит. Данните от праговата аудиометрия корелираха с обективното състояние на тъпанчевата мембрана на дясното ухо. При други 15 пациенти (23.81\%) регистрирахме абнормни аудиограми, като при 4 от тях се касаеше за комбинирано намаление на слуха. Регистрираната от нас средна стойност на въздушния праг на слуха за дясното ухо беше в границите $19.68 \div 22.17 \mathrm{~dB}$, а тази за лявото ухо съответно $17.53 \div 19.12 \mathrm{~dB}$. При изследването на костната проводимост отчетохме стойности за дясното ухо в границите $9.04 \div 11.11 \mathrm{~dB}$, а за лявото $-7.53 \div 8.65 \mathrm{~dB}$. Средните стойности за минимален праг на слуха за въздушната проводимост на дясното и лявото ухо варират, като тези на дясното ухо са над $20 \mathrm{~dB}$, а тези на лявото ухо - под посочената стойност (Фиг. 2).
Фиг. 2. Диаграма на разпределението на основните статистически данни, касаещи минималния праг на слуха при съответните честоти за двете уши (d-дясно ухо; s-ляво ухо)

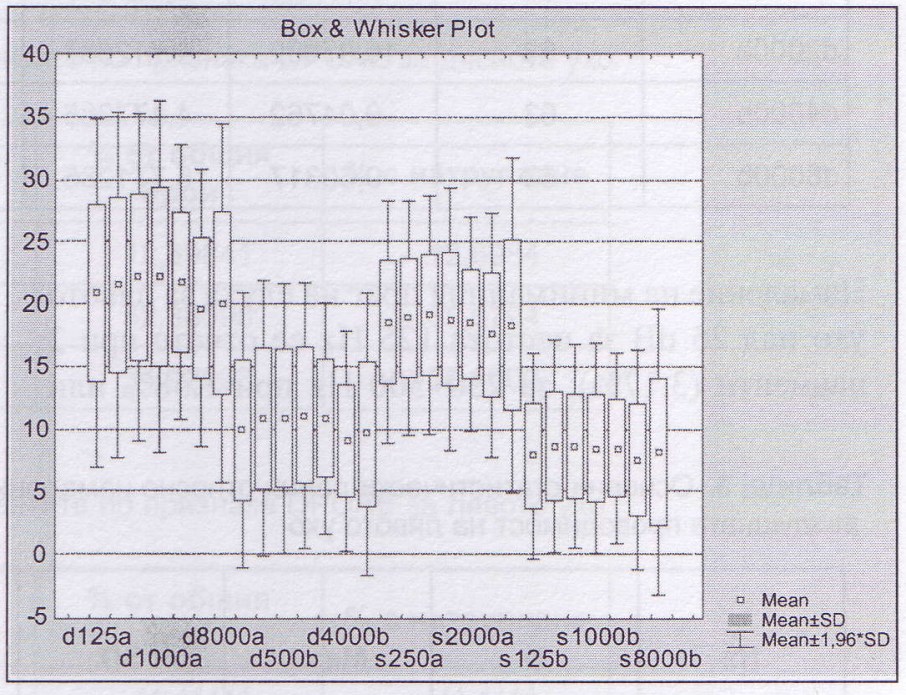

1000 и $2000 \mathrm{~Hz}$ при 9 пациенти (14.28\%); за 4000 $\mathrm{Hz}$ при 5 пациенти (7.92\%); за $8000 \mathrm{~Hz}$ при 10 пациенти (15.85\%) (Табл. 1).
Намаление на минималния праг на слуха за дясното ухо над $25 \mathrm{~dB}$ за честота $125 \mathrm{~Hz}$ се отчете при 8 пациенти (12.69\%); за $250 \mathrm{~Hz}$ при 7 пациенти (11.10\%); за $500 \mathrm{~Hz}$ при 11 пациенти (17.74\%); за

Таблица 1. Основни статистически данни относно намалението на слуха в $\mathrm{dB}$ за въздушната проводимост на дясното ухо.

\begin{tabular}{|c|c|c|c|c|c|c|c|}
\hline $\mathrm{Hz}$ & $\mathbf{N}$ & Mean & SD & Min & Max & $\begin{array}{c}\text { Брой с } \\
\text { намален } \\
\text { слух над } 25 \\
\text { dB }\end{array}$ & $\begin{array}{c}\text { Брой с } \\
\text { намален } \\
\text { слух над } 25 \\
\text { dB } \\
{[\%]}\end{array}$ \\
\hline d125a & 63 & 20,87302 & 7,101776 & 5,00 & 50,00 & 8 & 12,69 \\
\hline d250a & 63 & 21,50794 & 7,050219 & 0,00 & 50,00 & 7 & 11,10 \\
\hline d500a & 63 & 22,12698 & 6,685304 & 10,00 & 50,00 & 11 & 17,74 \\
\hline d1000a & 63 & 22,17460 & 7,174191 & 10,00 & 50,00 & 9 & 14,28 \\
\hline $\mathrm{d} 2000 \mathrm{a}$ & 63 & 21,74603 & 5,619575 & 10,00 & 35,00 & 9 & 14,28 \\
\hline $\mathrm{d} 4000 \mathrm{a}$ & 63 & 19,68254 & 5,670596 & 5,00 & 40,00 & 5 & 7,92 \\
\hline d8000a & 63 & 20,07937 & 7,322748 & 10,00 & 45,00 & 10 & 15,85 \\
\hline
\end{tabular}


Стойности на минималния праг на слуха за костна проводимост на дясното ухо над $15 \mathrm{~dB}$ при честота $125 \mathrm{~Hz}$ бяха отчетени при 4 пациенти $(6.44 \%)$, за $250 \mathrm{~Hz}$ при $7.92 \%$ (5 пациента); за 500 и $2000 \mathrm{~Hz}$ при 7 пациенти (11.11\%); за 1000 и $8000 \mathrm{~Hz}$ при 8 пациенти $(12.96 \%)$ и за $4000 \mathrm{~Hz}$ при 3 пациенти $(4.76 \%)$ (Табл. 2).

Таблица 2. Основни статистически данни относно намалението на слуха в dB за костната проводимост на дясното ухо

\begin{tabular}{|l|c|c|c|c|c|c|c|}
\hline & N & Mean & SD & Min & Max & $\begin{array}{c}\text { Брой c } \\
\text { намален } \\
\text { слух над 15 } \\
\text { dB }\end{array}$ & $\begin{array}{c}\text { Брой с нама- } \\
\text { лен слух над } \\
15 \text { dB } \\
{[\%]}\end{array}$ \\
\hline d125b & 63 & 9,90476 & 5,615975 & 0,00 & 30,00 & 4 & 6,44 \\
\hline d250b & 63 & 10,85714 & 5,622125 & 0,00 & 30,00 & 5 & 7,92 \\
\hline d500b & 63 & 10,87302 & 5,502176 & 0,00 & 30,00 & 7 & 11,11 \\
\hline d1000b & 63 & 11,11111 & 5,421317 & 0,00 & 25,00 & 8 & 12,96 \\
\hline d2000b & 63 & 10,87302 & 4,712687 & 0,00 & 20,00 & 7 & 11,11 \\
\hline d4000b & 63 & 9,04762 & 4,477285 & 0,00 & 20,00 & 3 & 4,76 \\
\hline d8000b & 63 & 9,60317 & 5,771285 & 0,00 & 25,00 & 7 & 12,96 \\
\hline
\end{tabular}

Намаление на минималния праг на слуха за лявото ухо над $25 \mathrm{~dB}$ за честота $125 \mathrm{~Hz}$ се отчете при 2 пациенти $(3.17 \%)$; за $250 \div 500 \mathrm{~Hz}$ при $1.58 \%$ или
1 пациент; за 1000 и $4000 \mathrm{~Hz}$ при $3.17 \%$ (2 пациенти); за $2000 \mathrm{~Hz}$ при 3 (4.76\%); за $8000 \mathrm{~Hz}$ при 5 пациенти (7.92\%) (Табл. 3).

Таблица 3. Основни статистически данни относно намалението на слуха в dB за въздушната проводимост на лявото ухо

\begin{tabular}{|c|c|c|c|c|c|c|c|}
\hline Hz & N & Mean & SD & Min & Max & $\begin{array}{c}\text { Брой c } \\
\text { намален } \\
\text { слух над 25 } \\
\text { dB }\end{array}$ & $\begin{array}{c}\text { Брой с нама- } \\
\text { лен слух над } \\
\text { 25 dB } \\
{[\%]}\end{array}$ \\
\hline s125a & 63 & 18,57143 & 4,953703 & 10,00 & 30,00 & 2 & 3,17 \\
\hline s250a & 63 & 18,88889 & 4,789475 & 10,00 & 30,00 & 1 & 1,58 \\
\hline s500a & 63 & 19,12698 & 4,880812 & 5,00 & 30,00 & 1 & 1,58 \\
\hline s1000a & 63 & 18,80952 & 5,366735 & 5,00 & 40,00 & 2 & 3,17 \\
\hline s2000a & 63 & 18,41270 & 4,383381 & 10,00 & 30,00 & 3 & 4,76 \\
\hline s4000a & 63 & 17,53968 & 4,989749 & 10,00 & 35,00 & 2 & 3,17 \\
\hline s8000a & 63 & 18,33333 & 6,839166 & 5,00 & 40,00 & 5 & 7,92 \\
\hline
\end{tabular}

Стойности на минималния праг на слуха за костна проводимост на лявото ухо над $15 \mathrm{~dB}$ при честота $125 \div 500 \mathrm{~Hz}$ не бяха отчетени при нито един от пациентите; за $1000 \mathrm{~Hz}$ при 1 пациент (1.58\%); за $2000 \div 4000 \mathrm{~Hz}$ при 2 пациенти $(3.17 \%)$ и за $8000 \mathrm{~Hz}$ при 5 пациенти (7.92\%) (Табл. 4).

При всички 63 пациенти беше извършено обективно изследване на слуха чрез DPOAE. Прави впечатление фактьт, че малка част от пациентите (8 за дясно ухо и 7 за ляво) са показали положителен отговор на скрининг-теста. При $34.92 \%$ за дясното ухо и при $33.33 \%$ за лявото ухо скрининг-тестьт не отчита положителна реакция. Отрицателните отговори са съответно 33 (52.38\%) за дясното ухо и $35(55.55 \%)$ за лявото ухо. Желателно е изследването за отоакустични емисии да бъде повторено съгласно протокола за изследване (Табл. 5, 6). При 11 пациенти (17.46\%) бяха направени слухови стволови евокирани потенциали. При всички изследвани пациенти с изклюение на един се регистрира V-вълна при $35 \mathrm{~dB}$ двустранно след click-стимулация. 
Таблица 4. Основни статистически данни относно намалението на слуха в dB за костната проводимост на лявото ухо

\begin{tabular}{|c|c|c|c|c|c|c|c|}
\hline Hz & N & Mean & SD & Min & Max & $\begin{array}{c}\text { Брой c } \\
\text { намален } \\
\text { слух над 15 } \\
\text { dB }\end{array}$ & $\begin{array}{c}\text { Брой с нама- } \\
\text { лен слух над } \\
15 \text { dB } \\
{[\%]}\end{array}$ \\
\hline S125b & 63 & 7,85714 & 4,184677 & 0,00 & 15,00 & 0 & 0 \\
\hline S250b & 63 & 8,65079 & 4,326060 & 0,00 & 15,00 & 0 & 0 \\
\hline S500b & 63 & 8,63492 & 4,151570 & 0,00 & 15,00 & 0 & 0 \\
\hline s1000b & 63 & 8,49206 & 4,272466 & 0,00 & 25,00 & 1 & 1,58 \\
\hline s2000b & 63 & 8,49206 & 3,876617 & 0,00 & 20,00 & 2 & 3,17 \\
\hline s4000b & 63 & 7,53968 & 4,478715 & 0,00 & 20,00 & 2 & 3,17 \\
\hline s8000b & 63 & 8,17460 & 5,840735 & 0,00 & 25,00 & 5 & 7,92 \\
\hline
\end{tabular}

Таблица 5. Разпределение на пациентите по признака DPOAE за дясното ухо

\begin{tabular}{|l|c|c|c|}
\hline & Брой & $\begin{array}{c}\text { \% от общия } \\
\text { брой }\end{array}$ & \% с натрупване \\
\hline pass & 8 & 12,69841 & 12,6984 \\
\hline refer & 33 & 52,38095 & 65,0794 \\
\hline noisy & 22 & 34,92063 & 100,0000 \\
\hline
\end{tabular}

Таблица 6. Разпределение на пациентите по признака DPOAE за лявото ухо

\begin{tabular}{|l|c|c|c|}
\hline & Брой & $\begin{array}{c}\text { \% от общия } \\
\text { брой }\end{array}$ & \% с натрупване \\
\hline Pass & 7 & 11,11111 & 11,1111 \\
\hline Refer & 35 & 55,55556 & 66,6667 \\
\hline Noisy & 21 & 33,33333 & 100,0000 \\
\hline
\end{tabular}

\section{Обсъждане}

Освен невросензорна слухова загуба при пациентите с $\beta$-таласемия се установява и звукопроводно намаление на слуха, дължащо се на тонзиларна хипертрофия, аденоидна вегетация, отити, тубарна дисфункция [8].

Cuda et al. описват аудиометрични резултати от изследване на 50 пациенти с хомозиготна $\beta$-таласемия, като определят честота на високочестотната слухова загуба в рамките на $14 \div 26 \%$, като установяват корелация между нивата на Deferoxamine и степента на слуховата загуба [3]. Регистрираната от тях високочестотна слухова загуба е със 7-10\% по-висока от честотата на този вид слухова загуба в общата популация. De Espana et al. изследват слуховата функция чрез прагова и високочестотна аудиометрия и евокирани слухови стволови потенциали на 20 пациенти, подложени на редовна хемотрансфузионна и хелатираща терапия с Deferoxamine и установяват невросензорна слухова загуба при $15 \%$ от пациентите [4]. Това дава основание авторите да заключат, че ототоксичният ефект на Deferoxamine съществува, макар и той да е минимален. Sacco et al. документират при пациенти с $\beta$-таласемия честота на невросензорната загуба на слуха в рамките на $19,4 \%$, като според тях тя зависи от дозировката на Deferoxamine и серумното ниво на феритина [9]. Kontzoglou et al. мониторират 104 болни с $\beta$-таласемия, като при $20,2 \%$ те откриват невросензорна слухова загуба, уни- или билатерално [6]. Ambrosetti et al. установяват чрез отологичен преглед прагова аудиометрия и импедансметрия при $57 \beta$-таласемично болни пациенти на редовна хелатираща терапия с 
Deferoxamine в доза $30 \div 50 \mathrm{mg} / \mathrm{kg} / 24 \mathrm{~h}$ кондуктивна слухова загуба при 4 пациенти и сензоневрален високочестотен аудиторен дефицит при $22,8 \%$ от пациентите [1]. Ние установяваме при 15 от изследваните от нас 63 пациенти с $\beta$-таласемия $(23,81 \%)$ абнормни аудиограми - лекостепенна невросензорна слухова загуба, а при 4 от тях се касае за комбинирано намаление на слуха.

\section{Изводи}

- Получените от нас резултати при изследването на слуховата функция на пациенти с таласемичен синдром не се отличават съществено от данните в достъпната ни литература. Регистрираният слухов дефицит е в границите на социално адекватния слух и не смущава социалната адаптация на пациентите.

\section{Литература:}

1. Ambrosetti U, Donde E, Piatti G, Cappellini MD. Audiological evaluation in adult beta-thalassemia major patients under regular chelation treatment. Pharmacol Res. 2000; 42(5): 485-7.

2. Cohen A, Martin M, Mizanin J, Konkle DF, Schwartz E. Vision and hearing during deferoxamine therapy. J Pediatr. 1990; 117 (2 Pt 1): 32630.

3. Cuda D, De Benedetto M, Leante M, Corvaglia E. The prevalence and evolution of hypoacusis in Cooley's disease Acta Otorhinolaryngol Ital. 1991; 11(5): 471-81.

4. De Espana R, Biurrun O, Lorente J, Valls J, Orteu N, Traserra J. Ototoxicity of deferoxamine. An Otorrinolaringol Ibero Am. 1992; 19(4): 341-7.

5. De Sanctis V, Pinamonti A, Di Palma A, Sprocati M, Atti G, Gamberini MR, Vullo C. Growth and development in thalassaemia major patients with severe bone lesions due to desferrioxamine. Eur J Pediatr. 1996 155(5): 368-72.
- Като основна причина за хипоакузис при пациентите с таласемия повечето автори изтъкват ототоксичното въздействие на хелатиращия агент Deferoxamine. Във високи дози Deferoxamine проявява ототоксичност, като при част от болните след оптимизиране на схемата на лечение и терапевтичната доза слуховата загуба е обратима.

Единно остава мнението, че за профилактика на слуховите нарушения при пациентите с таласемичен синдром е необходимо аудиологично проследяване и оптимизиране на терапията на таласемичния синдром, предвид невросензорната токсичност на хелатиращия агент Deferoxamine methane sulphonate (Desferal).

6. Kontzoglou G, Koussi A, Economou M, Tsatra I, Perifanis V, Noussios G, Athanassiou-Metaxa M. Long term audiological cvaluation of betathalassemic patients. Acta Otorhinolaryngol Belg. 2004; 58(2): 113-7.

7. Luzzato $\mathrm{L}$ et al. Increased suckling of parasitized erythrocytes as mechanism of resistance against malaria in the sickle-cell trait. Lancet, 1970, 1:319.

8. Onerci M, Aslan S, Gumruk F, Aksoy S, Belgin E, Ozcelik T, Altay C. Audiologic and impedancemetric findings within thalassaemic patients. Int J Pediatr Otorhinolaryngol. 1994; 28(2-3): 167-72.

9. Sacco M, Meleleo D, Tricarico N, Greco Miani A, Serra E, Parlatore L. Evaluation of desferrioxamine ototoxicity in thalassemic patients. Follow-up over a 5-year period and results. Minerva Pediatr. 1994; 46(5): 225-30.

10. Лаборатория по молекулярна патология: $\beta$-таласемия (ОМІМ 141900), СБАЛАГ „Майчин дом“, Медицински унивсрситет София; http://www.lmpbg.org/lib/dd1.htm. 